\title{
THE POLITICS OF PROMISE OR THREAT AND THE PRAXIS OF HOPE: MODELING A LINGUISTIC- PHENOMENOLOGICAL EPISTEMOLOGY OF PRACTICE FOR THE ASSESSMENT OF ALTERNATIVE WORLDVIEWS IN MEDIA LITERACY
}

Zdzisław Wąsik ${ }^{1}$

\begin{abstract}
At the outset, I discuss selected conceptions of world images put forward by philosophers pertaining to human experience and the social construction of reality. Herewith, I am trying to clarify distinctions between appearances and experiences of things in the world and the abilities of humans to construe worlds beyond words, along with their being-in-world, and experiencing their in-the-world existence. Subsequently, I confront some epistemological theories about the complexity of scientific knowledge of the world and its fragmentary perception in psychophysiological cognition. What is relevant for the theme, I present the methods of the lived-through research in dealing with the ideology of promise or threat expressed by leaders of social movements who offer a hope for better worlds which are not here and not now but can be achieved in the future. Lastly, I submit proposals to approach the relationships between world and reality in their hierarchical ordering and semiotic modeling.
\end{abstract}

KEYWORDS: Linguistical epistemology. Phenomenology of practice. Alternative worlds. Media literacy. Experiential knowledge.

\footnotetext{
1 Philological School of Higher Education, Wrocław - Polond. Rector Senior and Professor of Linguistics, Semiotics and Communicology. Orcid: https://orcid.org/0000-0003-2556-8228. E-mail: zdzis.wasik@gmail.com
} 
The politics of promise or threat and the praxis of hope: modeling a linguistic-phenomenological epistemology of practice for the assessment of alternative worldviews in media literacy

\section{A POLITICA DA PROMESSA OU AMEAÇA E A PRAXIS DA ESPERANÇA: PROPOSTA DE MODELO A UMA EPISTEMOLOGIA LINGUISTICO- FENOMENOLÓGICA DA PRÁTICA PARA A AVALIAÇÃO DE VISÕES MUNDIAIS ALTERNATIVAS NA COMPETENNCIA MIDIÁTICA}

RESUMO: Iniciamos este artigo discutindo uma seleção de conceitos de imagens do mundo problematizados por filósofos que pertencem a correntes dedicadas ao estudo da experiência humana e da construção social da realidade. Assim, tentamos esclarecer a distinção entre fenômeno e experiência das coisas do mundo, além de discorrermos sobre a capacidade das pessoas de interpretar e construir mundos além das palavras, considerando o ser no mundo do sujeito em sua experiência de existência-no-mundo. Em seguida, confrontamos algumas teorias epistemológicas que versam sobre a complexidade do conhecimento cientifico do mundo e sua percep̧ção fragmentada na cognição psicofisiológica. Destacamos que uma relevante contribuição para o tema é a apresentação, neste trabalho, de métodos de pesquisa sobre o mundo vivido ao lidar com a ideologia da promessa ou ameaça feita por líderes de movimentos sociais que oferecem uma esperança por mundos melhores que não se apresentam atualmente, mas poderiam ser alcançados no futuro. Por fim, apresentamos propostas para abordar as relaçôes entre mundo e realidade em sua ordenação hierárquica e sua modelagem semiótica.

PALAVRAS-CHAVE: Epistemologia linguística. Fenomenologia da prática. Mundos alternativos. Competência midiática. Conhecimento experiencial.

\section{POLITYKA OBIECYWANIA LUB GROŻENIA A PRAKTYKA NADZIEI: MODELOWANIE LINGWISTYCZNO-FENOMENOLOGICZNEJ EPISTEMOLOGII STOSOWANEJ DLA OCENIANIA ALTERNATYWNYCH WIZJI ŚWIATA W KOMPETENCJI MEDIALNEJ}

STRESZCZENIE: Na wstępie omawiam wybrane koncepcje widzenia świata przedktadane przez filozofów, odnoszące się do doświadczenia człowieka i spotecznego tworzenia rzeczywistości. Tutaj staram się wyjaśnić rozróżnienia między zjawiskami a doświadczeniami rzeczy $w$ świecie $i$ zdolności ludzi do konstruowania światów poza stowami, wraz z ich byciem w świecie i wtasnym doświadczaniem świata życia. Następnie konfrontuję niektóre teorie epistemologiczne o ztożoności wiedzy naukowej o świecie i jego fragmentarycznej percepcji w psychofizjologicznym poznawaniu. Co jest istotne dla tematu, przedstawiam metody badań nad światem przeżywanym przy zajmowaniu się ideologia obiecywania lub 
grożenia wyrażana przez liderów ruchów spotecznych, którzy oferują nadzieje na lepszy świat, jakiego nie ma tu i teraz, ale jakie moga być osiagnięte w przysztości. Na końcu też zgtaszam postulat, aby badać relacje między światem a rzeczywistościa w ich hierarchicznym uporzadkowaniu i modelowaniu semiotycznym.

SEOWA KLUCZOWE: Epistemologia lingwistyczna. Fenomenologia praktyczna. Światy Alternatywne. Kompetencja medialna. Wiedza doświadczalna.

\section{Introductory remarks on the scope and content of the paper}

This paper aims at elaborating a theoretical model for the evaluation of the political strategies of cosmological discourse, in which the participants of social communication are obliged to make a choice between competing visions of their lifeworld. It departs from the ideological stances of social movements, manifestos or programs, prevailing in media literacy, that are conveyed by members of interest or pressure group, or political fractions, through public or mass communication channels.

In these forms of communication, the involved authors/senders offer something new, based on the ontology of not-yet-being, under the arguments of promise or threat, whereas the addressees/receivers are expected to adjust their conduct in the hope that the reality will change according to the assured predictions or portrayed anticipations. The investigative subject matter of this paper constitutes the epistemological deconstruction of the mere concept of worldhood being present in opening addresses formulated for populistic purposes by various organizers of everyday life (politicians, scientists or spiritual leaders) who claim to start a new era by introducing something original what has not existed before, an innovative paradigm of thinking, a unique vision of human lifeworld.

As regards the investigative methodology, the paper alludes to experiential sources of human knowledge about the world, merging the mundane and transcendentalist phenomenology with epistemology. Epistemology is presented here not only as set of investigative perspectives or as psychosomatic ability of a cognizer, but also as a narrative activity of a knower. What has been launched as a novelty is the author's conception of the linguistic-phenomenological epistemology of practice that considers the complexity of knowledge about the human world and the fragmentarity of its cognition. In such a cosmological conception, the reality of everyday life is shown as experienced through the man's being-in-theworld, where his 'life-world' appears to be a 'lived-through' world. 
Finally, the paper puts forward some investigative postulates for discussing the relationship between world and reality in order to show the incompatibilities of worldviews in the psychophysiological perception of reality, hierarchies of worlds and semiotic modeling systems, and creative aspects of epistemic ability to construe phenomenal worlds beyond words. To sum up, the submitted proposal of a paper is merging the epistemology of cognition and phenomenology of experience, as an investigative perspective, with metaphysical cosmology, as a subject matter of investigation, in relation to the linguistic semiotics of political communication as an investigative domain.

\section{Phenomenological conceptions of worldhood}

\section{Phenomenology as the study of appearances of lifeworld in human experience}

Even that the notion of phenomenology goes back to the times of Immanuel Kant's Critique of pure reason [Critik der reinen Vernunft] (KANT, 1838 [1781]. and Georg Wilhelm Friedrich Hegel's Phenomenology of mind [Die Phänomenologie des Geistes] (HEGEL, 1910 [1807]), the current paradigm of phenomenology dates from the philosophy of Edmund Husserl. What Husserl has proposed - in his lectures held at Prague in 1935 and Vienna in 1936, Die Krisis der europäischen Wissenschaften und die transzendentale Phänomenologie: Eine Einleitung in die phänomenologische Philosophie, published for the first time in 1954 and translated into English in 1970 as The crisis of European sciences and transcendental phenomenology: An introduction to phenomenological philosophy - is the study about appearances of perceptible lifeworld objects in human experience (HUSSERL, 1970 [1954]).

Inquiring into the ways how human individuals experience and describe, in the first-person perspective, the meanings of objects their lifeworld, Husserl distinguishes three kinds of phenomenology namely, transcendental, existential, and mundane (Germ. Lebenswelt the lifeworld".) phenomenology. From Husserl's reasoning, one can deduce that the phenomenological conception of world connotes not only a dualistic split between empirical and rational facts, encompassing as such two distinct worlds, the world of nature and the psychic world (HUSSERL, 1970 [1954]), but also generates "a psychophysical anthropology in the rationalistic spirit” (HUSSERL, 1970 [1954], p.62, cf. quoted and cited WĄSIK, 2018, p.128). 
Following Husserl's interpretation, the phenomenological conception of world overcomes the hitherto prevailing opposition between empiricism and rationalism, to that extent that it includes simultaneously the spiritual world, the ideal world and the human lifeworld (cf. HUSSERL, 1970 [1954], p.62). The Lebenswelt (lifeworld), constituting the domain of mundane phenomenology, is the world in which people live together, about its existence they are conscious, and to which they belong. At this juncture, the following definition of Lebenswelt, launched in Husserl's lectures of 1935-1936, has become the mostly quoted and discussed assertion:

In whatever way we may be conscious of the world as universal horizon, as coherent universe of existing objects, we, each "I-the-man" and all of us together, belong to the world as living with one another in the world; and the world is our world, valid for our consciousness as existing precisely through this "living together". (HUSSERL, 1970 [1954], p.108; cited and quoted after WĄSIK, 2018, p.128).

Along these lines, Husserl's idea of 'lifeworld' requires a more accurate concern of human subjectivity and objectivity, when considering that "to live" constantly means "to live-in-certainty-of-the-world". As Husserl assumes, waking life is being awake to the world, being constantly and directly conscious of the world and oneself as living in the world, actually experiencing, or livingthrough [erleben] and actually effecting the ontic certitude of the world. By this means, the world is pregiven in a way in which individual objects are always given. Still, there exists a fundamental difference between the way one is conscious of the world and the way one is conscious of its objects (as constituents of the lifeworld), though together the two make up an inseparable unity (HUSSERL 1970 [1954], p.142-143; cited and quoted after WĄSIK, 2018, p.129).

In the extended versions, there are also some other orientations in phenomenology, which have been summarized and elaborated by Max van Manen on Phenomenology online. a resource from phenomenological inquiry. Respectively, van Manen puts forward the following typological distinctions: (1) transcendental phenomenology, (2) existential phenomenology, (3) hermeneutical phenomenology, (4) linguistical phenomenology, (5) ethical phenomenology, and (6) phenomenology of praxis (cf. VAN MANEN, 2011). 


\section{Creative aspects of epistemic ability to construe phenomenal worlds beyond words}

Husserl's conception of Lebenswelt has been developed withing the framework of mundane phenomenology. In allusion to mundane phenomenology, developed since the 1930s after the German thought of Alfred Schütz in the book Der sinnhafte Aufbau der sozialen Welt ('The senseful construction of the social world', SCHÜTZ, 1932), and published in the 1970s by Alfred Schütz and Thomas Luckmann in their book The structures of the life-world (SCHÜTZ; LUCKMANN, 1973 [1975]).

It is worth recalling the idea of social construction of reality from the late 1960s, based on the assumption that people create their own view of the world they live in on the basis of reflections of their individual experiences. Sociological constructivists take for granted that the reality of everyday life is shaped by information gained by particular human beings as organisms in interactions with their environment. Personal constructs result therefore not only from a similar perception of the world but also from analogous attitudes towards the objects evaluated with respect to their utility.

Social constructivists suppose that interpersonal communication can lead to creating intersubjectively similar personal constructs in the minds of people interacting within the same culture. As pointed out by Peter Ludwig Berger and Thomas Luckmann, in The social construction of reality, man is a social being and his contacts with external environments is mediated by symbols (BERGER; LUCKMANN, 1966). Hence, it is language which "[...] objectivates the shared experiences and makes them available to all within linguistic community, thus becoming both the basis and the instrument of the collective stock of knowledge." (BERGER; LUCKMANN, 1966, p.68).

What is more, his collective stock of everyday knowledge is created due to social interactions. A certain kind of a social construct is the reality of everyday life, or the world of life, which comes into being as a result of communicational activities (cf. BERGER; LUCKMANN, 1966, p.19-46). As Peter L. Berger and Thomas Luckmann have stated: "The reality of everyday life" appears to individual selves "as an intersubjective world, a world that" they "share with others". However. this intersubjectively comprehended world "sharply differentiates everyday life from other realities of which" they are aware (BERGER; LUCKMANN, 1966, p.23). 
The worldhood of real world experienced through man's being-inthe-world

The existential relationship of the human subject with the world, in which he lives, should especially be brought to light on the basis of Heidegger's works with special reference to Being and time [Sein und Zeit] (HEIDEGGER, 1962 [1927]), On the essence of ground, 1998 [Vom Wesen des Grundes] (HEIDEGGER, 1998 [1929]) and The fundamental concepts of metaphysics [Die Grundbegriffe der Metaphysik] (HEIDEGGER, 1995 [1983]).

As Heidegger noted in 1929, Sein und Zeit constitutes the second of his three different approaches to the problem of the world (cf. Being and time, HEIDEGGER, 1995 [1983], p.176-177). The first approach in "Vom Wesen des Grundes" deals with the historical development of the word and the concept of world (cf. On the essence of ground, HEIDEGGER, 1998 [1929]). The second approach, in Sein und Zeit (1926-1927), addresses "[...] the phenomenon of world by interpreting the way in which we at first and for the most part move about in our everyday world." (see HEIDEGGER, 1995 [1983], p.177]). And, the third one, discussed in its turn in Die Grundbegriffe der Metaphysik (1929-1930), is based on a "comparative examination" of man, animals, plants and stones (see The fundamental concepts of metaphysics, HEIDEGGER, 1995 [1983], p.177).

What makes Sein und Zeit distinctive is its emphasis on the world not as a concept but as a phenomenon (das Weltphänomen). A phenomenon describes something that becomes "manifest" and "shows itself in itself" (see HEIDEGGER, 1962 [1927], p.28-29]).

Thus, the world as a phenomenon should give us the world itself. As Heidegger explains in The fundamental concepts of metaphysics, his attempt was "[...] to provide a preliminary characterization of the phenomenon of world by interpreting the way in which we at first and for the most part move about in our everyday life." (see HEIDEGGER, 1995 [1983], p.177).

Following Heidegger's path of reasoning, how he approaches the world from the vantage point of Dasein, as being-in-the-world, we might therefore grasp the phenomenon of the world: "That which is so close and intelligible to us in our everyday dealings is actually and fundamentally remote and unintelligible to us." (see HEIDEGGER, 1995 [1983], p.177).

What Heidegger addresses in his third approach are thus the three concepts, namely 'world', 'finitude', and 'solitude', which form a unity. 
The discussion of animality must therefore be contextualized as belonging to this broader analysis of metaphysics and the essence of man. Without a doubt, Heidegger's famous tripartite thesis constitutes an attempt to understand the essence of "the other beings which, like man, are also part of the world", with regard to their relationship to and difference from the "having world" that marks man: "[1.] the stone (material object) is wordless; [2.] the animal is poor in world; [3.] man is world-forming" (HEIDEGGER, 1995 [1983], p.177). Finally, considering Being and time [Sein und Zeit], one shoulds make reference to Heidegger's history- and memory-oriented typology of at least four existentialist attitudes towards the human being-in-the-world (HEIDEGGER, 1962 [1927], p.424-449), as derivation/genesis (HEIDEGGER, 1962 [1927], p.444), event/transformation (HEIDEGGER, 1962 [1927], p.430), or heritage/legacy (HEIDEGGER, 1962 [1927], p.435), past/alien previousness (HEIDEGGER, 1962 [1927], p.448).

\section{From life-world over being-in-the world to lived-though world}

To trace the way, in which the human life-world (Edmund Husserl's Lebenswelt) turned out to change from being-in-the-world (Martin Heidegger's Dasein) to lived-through-world (Maurice Merleau-Ponty's monde vécu), one should estimate the statement from, Phenomenology of perception [Phénomènologie de la perception]: "The process of making explicit, which had laid bare the 'lived-through' world which is prior to the objective one, is put into operation upon the 'lived-through' world itself, thus revealing, prior to the phenomenal field, the transcendental field." (see MERLEAU-PONTY, 2005 [1945], p.73).

What is remarkable, Merleau-Ponty emphasizes that: "Consciousness is being-towards-the-thing through the intermediary of the body. A movement is learned when the body has understood it, that is, when it has incorporated it into its 'world', and to move one's body is to aim at things through it; it is to allow oneself to respond to their call, which is made upon it independently of any representation." (MERLEAU-PONTY, 2005 [1945], p.159-161).

The direction of interpretative reasoning inaugurated by Merleau-Ponty has been undertaken by Max van Manen who has used in his Researching human experience: human science for an action sensitive pedagogy (VAN MANEN, 1997 [1989]), the phenomenological notion of lifeworld existentials to explore and understand the world of the lived experience. An extensive exploration of phenomenological traditions and methods for the human sciences, such 
as psychology, education, health care, and everyday living, is culminated in van Manen's, Phenomenology of practice: meaning-giving methods in phenomenological research and writing (VAN MANEN, 2014).

Above all, the applications of interpretative or hermeneutic terms have appeared to be very productive, such as "lived life", "lived meaning", or "lived experience". To be exact, while confronting Husserl's interpretation of lifeworld as "to live-in-certainty-of-the-world", one can could be entitled to assume that van Manen's idea has been to account for the formula "to practically experience the existential dimensions of the lived-through world". Even having been widely distributed, the so called "essential themes" pertaining to the analysis of lived experience, called otherwise "lifeworld existentials" - initially four in number - (1) lived body (corporeality), (2) lived human relation or lived selfother (relationality), (3) lived space (spatiality), and lived time (temporality) as analytic tools (cited after VAN MANEN, 1997 [1989], p.18, p.27, p.31-35, and further pages),

In his later article, "Phenomenology of practice", van Manen implicitly formulates his conviction that "Phenomenology of practice is formative of sensitive practice, issuing from the pathic power of phenomenological reflections. Pathic knowing inheres in the sense and sensuality of our practical actions, in encounters with others and in the ways that our bodies are responsive to the things of our world and to the situations and relations in which we find ourselves." (VAN MANEN, 2007, p.11). Claiming that: "A phenomenology of practice grasps the world pathically" (VAN MANEN, 2007, p.20), van Manen explains that "[...] the term pathic relates to the terms of a discourse, as in, empathic and sym-pathic. [...] more generally, to be understandingly engaged in other people's lives." (VAN MANEN, 2007, p.20 Emphasis our).

As van Manen further exhibits, despite the fact that the derivational basis of pathic is pathos, meaning 'suffering and also passion': "In a larger life context, the pathic refers to the general mood, sensibility, sensuality, and felt sense of being in the world." (VAN MANEN, 2007, p.21). Undoubtedly, Maurice Merleau-Ponty's statement: "Consciousness is being-towards-the-thing through the intermediary of the body. A movement is learned when the body has understood it, that is, when it has incorporated it into its 'world"' (MERLEAUPONTY, 2005 [1945], p.159-161) might be easily comparable with Max van Manen's ways of reasoning: "The pathically tuned body recognizes itself in its responsiveness to the things of its world and to the others who share our world or break into our world. The pathic sense perceives the world in a feeling or emotive modality of knowing and being." (VAN MANEN, 2007, p.11). 


\section{Ontological complexity of knowledge about the world and gnoseological fragmentizing of its perception}

\section{On the empiriocritical roots of antimetaphysical epistemology}

The search for the genesis of epistemology as an activity of acquiring the knowledge, or a way of arriving at a state of knowing, about the world an object of cognition, bearing in mind the imperfection and unreliability of perceptive powers of the human organism as an investigating subject, departs from the works of Gregory Bateson. published under the summarizing title Steps to an ecology of mind (BATESON, 1987), and subsequently to his monograph Mind and nature (BATESON, 1979). In most of his works, Bateson referred to the ideas of his preceptor Alfred Korzybski, the author of Science and sanity with regard to the epistemology of man as a holistic organism functioning in a determined environment (KORZYBSKI, 1933).

In Korzybski's reasoning, knowledge as a cumulative enterprise occurs where the partial epistemologies of individual scientists meet together in the collective wisdom of society constituting simultaneous communities or successive generations of scholars. Such epistemologies, being solipsistic and psychophysiological in nature, are defective, imperfect, and therefore incredible. Hence, the knowledge, resulting from the fallibility or unreliability of perception, must consider, firstly, the instability, polysemy, multiordinal situation of nonverbal and verbal means of communication, to which humans react, and which humans use in thinking activities, and secondly also, volatility and fragility as well as illusiveness of sensorial experiences, resulting from imperfection, distortion, or deficiency of cognizing organs. Henceforth, it seems essential to remind the classical cradles of epistemology equated with a theory of cognition relegating the knowledge about the being to metaphysics, rooted in two beliefs from the end of the nineteenth century, namely metaphysical epistemology and "scientificist" or scientific epistemology.

Metaphysical epistemology, in the appreciations of James Frederick Ferrier, was a subject-oriented theory of knowledge about the cognized objects based on the criterion of absolute truth (FERRIER, 1854). Scientific epistemology, considered as antimetaphysical by St. George Jackson Mivart, was associated with systematizing endeavors to achieve exhaustive knowledge about reality through sensorial observations and intellectual inquiries (MIVART, 1898).

Epistemology of organisms forming mental-sensorial consciousness in certain environments have been influenced by two philosophers Ernst Mach 
and Jacques Loeb. The principal role in the formation of Korzybski's conception of "fallacious epistemology" of the human mind played two empiriocritical contributions to the analysis of sensory impressions of Ernst Mach, under one title Contributions to the analysis of the sensations [Beiträge zur Analyse der Empfindungen] (MACH, 1987 [1886]), extended later in the 5th edition as The analysis of sensations and the relation of the physical to the psychical [Die Analyse der Empfindungen und das Verhältnis des Physischen zum Psychischen (MACH, 1914 [1906]), and the treatise of Richard Avenarius on the critics of pure experience, Kritik der reinen Erfahrung ('Critique of pure experience', AVENARIUS, 1888, 1890).

While reading Mach's Contributions to the analysis of the sensations one could notice that the idea about the abstraction-oriented ability of humans which occurs in their perception, depending upon free will, was undoubtedly borrowed from him. According to Mach, man (under normal conditionings) is endowed with a gift to a self-governed and conscious determination of his own viewpoint (cf. MACH, 1914 [1906], 1987 [1886]).

As Mach noticed:

Man possesses in its highest form the power of consciously and arbitrarily determining his point of view. He can at time disregard the most salient features of an object, and immediately thereafter give attention to its smallest details [...], he can rise at will to the most general abstractions or bury himself in the minutest particulars. The animal possesses this capacity in a far less degree. It does not assume a point of view, but is usually forced to it" (see MACH, 1914 [1906], 1987 [1886], p.6-7).

However, "No point of view has absolute, permanent validity. Each has importance only for some given end." (MACH, 1914 [1906], 1987 [1886], p.37).

In the climate of opinion when Mach developed his ideas, there were two comparative works on the physiology of the brain and psychology published by Jacques Loeb in under one common title, namely Einleitung in die vergleichende Gehirnphysiologie und vergleichende Psychologie: mit besonderer Berücksichtigung der wirbelloser Tiere, translated two years later as Comparative physiology of the brain and comparative psychology (LOEB, 1900 [1899]).

Being familiarized with Loeb's title, Comparative physiology of the brain and comparative psychology, dedicated nota bene to Ernest Mach who established as the first scholar, in the opinion of Loeb, the principles of "anti- 
metaphysical epistemology", one can encounter also the notion of "scientific epistemology" postulated by St. George Jackson Mivart in The groundwork of science. A study of epistemology (MIVART, 1898). Worth quoting is the statement of Loeb formulated in his "Preface" to Comparative physiology of the brain and comparative psychology: "Professor Ernst Mach, of Vienna, to whom this book is dedicated, was the first to establish the general principles of an antimetaphysical science." (LOEB, 1900 [1899], p.V-VI).

\section{Confronting the psychophysiological epistemology with metascientific epistemology}

A slightly different view of epistemology as a theory about the prospective state of the human's holistic knowledge, which is composed of a set of investigative perspectives, has been developed in my own works, among which the most representative are the books published in English, are An outline for lectures on the epistemology of semiotics (WAZSIK, 1998), Epistemological perspectives on linguistic semiotics (WĄSIK, 2003), Lectures on the epistemology of semiotics (WĄSIK, 2014), and From grammar to discourse: towards a solipsistic paradigm of semiotics (WĄSIK, 2016a).

Thus, I believe that the aim of epistemology is a profound critique and verification of the methodological plane by testing its coherence and evaluating its adequacy in its relation to the descriptive plane. An epistemological analysis of a given discipline consists in the examination of its ontological and gnoseological foundations to answer how far the commitment of scientists to their attendant views on their object of study corresponds to its investigative approachability. Hence, the study of epistemological positions of scientists is based on the conviction that the choice of a given investigative approach stipulates their outlook upon the nature of their investigated object.

In detaching investigative "perspectives" of cognizing subjects from cognized "properties" of investigated objects, I consider epistemology as a branch of the philosophy of science studying the nature of human knowledge principally accumulated in the body of theories and praxis which result from research activities of scientists who address respective questions connected with the ontological and gnoseological status of scientific objects and the methodology of scientific fields in particular. In consequence, I maintain that the ontological outlook usually coincides with the choice of conceptual and operational investigative tools providing a basis for the formulation of investigative postulates. 
Furthermore, I assume that on a metascientific level, the choice of an epistemological orientation determines the choice of an appropriate investigative perspective resulting both the accepted tasks of investigation and the nature of the investigated object. In consequence, the search for investigative perspectives, which take part in the specification of the subject matter of particular disciplines, commonly starts with an overview of the panorama of all hitherto existing ontological beliefs, doctrines, trends and directions of scientific conduct.

Having appreciated Gregory Bateson's psychophysiological approach to epistemology (BATESON, 1987 [1972], 1979), against the background of my metascientific conception of epistemology as a set of ontological and gnoseological perspectives testifying how the things exists in reality and how scientists can approach them in their investigations (WĄSIK, 2003, 2014, 2016a), I have juxtaposed two opposed kinds of the theory of knowledge, (cf. WĄSIK, 2016b) namely: (1) the epistemology in a cognitivist-constructivist sense, the aim of which is to analyze the process of cognizing reality as a critical arrival at knowledge about the object of study accessible to sensory perception and intellectual reception (cf. BATESON, 1987 [1972], 1979). (2) epistemology in a dispositional-perspectivistic sense as a certain set of certain attitudes and investigative standpoints referring to the assumptions how the investigative reality exists in its forms of manifestation, and how it is approachable in scientific cognitions (cf. WĄSIK, 2003, 2014, 2016a).

In both cases, i.e., in a cognitivist-constructivist sense and in a dispositional-perspectivistic sense, the point of departure is always the reference of epistemology to knowledge; however, in the case of a psychophysiological epistemology the question pertains to the knowledge of both being and cognition, and in the case of a metascientific epistemology, attention is thus paid to the organism of the cognizing subject as a corporeal-mental unity acquiring knowledge through personal experience, what leads in consequence to the acceptance of an epistemological pluralism.

\section{Launching the idea of an linguistic-phenomenological epistemology of practice}

Whereas (1) the psychophysiological epistemology has been assumed as a way of arriving at the state of knowing about an object of cognition with reference to the perceptive powers of a cognizing organism and (2) the metascientific epistemology has been defined as a set of ontological and gnoseological perspectives pertaining to the scientists' knowledge of how the things exists 
and how to access them in cognition, the hypothetical-deductive scaffold of (3) the linguistic-phenomenological epistemology will be tentatively referred to the practicing-researchers' knowledge considered as a set of texts created for the purposes of writing and communicating in the first person about the experiential reality of everyday life.

Making reference to Max van Manen's definition, I put forward a postulate to launch a unified framework of the linguistic-phenomenological epistemology of practice as a conceptual-methodological tool, which would treat the theory of knowledge in terms of a linguistic text. This framework in question will depart from the textual view of epistemology in relation to:

Knowledge as text: We can speak of phenomenological texts as knowledge in the same sense that we refer to other bodies of knowledge contained in books and documents. It is important to see, however, that the phenomenological text differs in the manner that meaning is embedded in the text. Phenomenological knowledge-as-text has cognitive and pathic, conceptual and poetic, informative and formative dimensions. (VAN MANEN, 2011).

In appreciating the understanding of phenomenology as textual embodiment of knowledge, as understanding of texts, and as a formative constituent of the personal stock of knowledge, one may distinguish its three meanings, relevant, as a matter of fact, for the scope of a narrative linguistic-phenomenological epistemology of practice. The first meaning is referred to the bodies of knowledge contained in all books and documents, the second to the reflective and discursive participation in the meaning-related production and interpretation of texts, and the third to the connection between knowledge and practice in the personal formation of a knowing self.

Although van Manen has claimed in Researching human experience, that "[...] the experience of lived time, lived space, lived body, and lived human relation) are preverbal and therefore hard to describe." (VAN MANEN, 1997 [1989], p.18), these lifeworld existentials may be considered in terms of commonly lived experiences, while using such descriptors as "lived word-ness (textuality)", or "lived sign-ness (semioticality)", with reference to the textual view of language and culture, or the so-called semiospheres of culture, promoted by Juri Lotman (Лотман, Юрий Михайлович), in his articles, “The semiotics of culture and the concept of a text” [Семиотика культуры и понятие текста] 
(LOTMAN, 1988 [1981]), and "On the semiosphere" [O семиосфере] (LOTMAN, 2005 [1984]).

\section{Promise or threat in the ideological stances of offering new worlds}

\section{Deconstructing the principle of hope in the fulfillment of dreams for a new world}

A good example for researching an anticipated world-model in terms of lived experiences, might be the world of hope as delineated in the works of Ernst Bloch, The principle of hope [Das Prinzip Hoffnung] (BLOCH, 1986 [1954, 1955, 1959], and Stefan Skrimshire, Politics of fear, practices of hope: depoliticisation and resistance in a time of terror (SKRIMSHIRE, 2009), namely, the world offered as a better place to live, in public or mass media communication, by individuals or interest groups (lobbies or cliques), grounding on the politics of promise or threat and implying the principle of hope to be shared by prospective communication participants.

For the purpose of this paper, it is right and proper quoting Bloch's conviction that "The emotion of hope goes out of itself, makes people broad instead of confining them, cannot know nearly enough of what it is that makes them inwardly aimed, of what may be allied to them outwardly. The work of this emotion requires people who throw themselves actively into what is becoming, to which they themselves belong." (BLOCH, 1986 [1954, 1955, 1959], p.3).

Bloch's reflections on the principle of hope evolves, against the background of his earlier works on the spirit of utopia, around the ought-to-be worlds anticipated in terms of things and ideas in human life that are projected but have not occurred yet. These forthcoming worlds consists thus of desirable qualities of already-present constituents, which have not become a true reality so far. There are two issues in this incessant hope for better places to live.

The first one is connected with a contemplative knowledge about the world, towards which human daydreams are oriented, and the second with the world that exists only in the hopeful future, the existence of which has not been reached yet. A more advanced in the interpretation of the principle of hope is Stefan Skrimshire's depiction of the promised novum of happiness. Against the background of extensively utilized Ernst Bloch's ideas, Skrimshire puts more emphasis on human motivation for generating changes, in order to achieve a better status quo or on the actions aiming at resistance and even revolts. Where the dreams of a satisfactory "coming" are faced with the occurrence of a fearful 
"now", there is usually a possibility for the state of war with no hope for end (SKRIMSHIRE, 2009).

\section{Interpreting the discursive practices of hope in terms of lifeworld existentials}

Speaking in favor of the privatization of beliefs in opposition to the politicization of public spheres, Stefan Skrimshire inquires "how resistance is able to apply the form of imagination that can break ideological closure, that is able to repoliticize public space and public imagination into a body that recreates its own world". For Skrimshire "the persistence of discursive dissent not only in precedent moments of the imagination of revolt, but as an integral part of any popular contestation of a dominant power", and what is more, "imagination" seems "to be essential in the active construction of reality, something that moves" the human selves "towards others and other social realities" (quoted and cited after SKRIMSHIRE, 2009, p.160).

As one may conclude, practices of hope occupy an intermediating position between the "immanence" of political strivings, what the people are fighting for "here and now", and a kind of transcendence of private aspirations, what the people believe in, even that it is always a horizon of the permanent "not-yet" (as it has been put by BLOCH, 1986 [1954, 1955, 1959], p.3). In sum, Stefan Skrimshire's research work on the experimental nature of hope is definitely applicable for the exploration of various practical responses to diverse areas of social activity, widespread through mass media, such as verbal and nonverbal propaganda, e.g., graffiti art, advertising discourse etc.

In a discursive analysis of Ernst Bloch's and Stefan Skrimshire's positions to the anticipatory worlds as a result of promise or fear, the adherents of Max van Manen's methodology might be willing to consider some characteristics of lived experiences in the domain of self-other interactions (relationality) in a sequence of steps, such as: lived hopefulness (expectability), assurance (promisibility), anticipation (foreseeability), adaptiveness (flexibility), responsiveness (docility), acquiescence (elasticity), positiveness (acceptability), versus lived oppositeness (resistability), disagreement (contestability), withdrawal (escapablity), evasiveness (repudiation-ability), unworldliness (alienation-ability), otherworldliness (transcendence-ability) etc. 


\section{Postulative forethoughts on the relationship between world and reality}

\section{Incompatibilities of worldviews in the psychophysiological perception of reality}

To begin with Bateson's belief, the mental image of world depends upon the perception of reality (BATESON, 1951, p.237), as, firstly: "a category of observables in opposition to mental phantasies", secondly, "a social construct"... determined by dissimilar viewpoints" and interpretations "in different cultures", thirdly, "a set of personal knowledge [...] acquired through observation and formulated through mental propositions", fourthly, "a kind of living through and coping with the world of phenomena on the basis of pleasure and gratification", and fifthly, "a pre-given factual" sphere "based on communication in opposition to the artificially created magical" sphere "based on rituals" (BATESON, 1951, p.239-242, quoted and cited after WĄSIK, 2016b, p.28-29).

\section{Hierarchies of worlds and semiotic modeling systems}

Among philosophical queries, it is the epistemological theory of Karl Popper (1972), which has been mostly quoted, contested or complemented. The following "three worlds or universes" might be distinguished as distinct domains of human knowledge, according to Popper's Objective knowledge. An evolutionary approach, "[...] first, the world of physical object or physical states, secondly, the world of states of consciousness, or mental states, or perhaps behavioral dispositions to act; and thirdly, the world of objective concepts of thought, especially of scientific and poetic thought and works of art." (POPPER, 1972, p.106).

As Geoffrey Leech admittedly remarks in his Principles of pragmatics (LEECH, 1983), Popper's main intention has been to justify that there is also such a third world, which entails the "objective 'knowledge", or the "knowledge 'without a knowing subject"' involving its formulation in linguistic theories (quoted and cited after LEECH, 1983, p.49). However, Popper has not claimed that his three-worlds conception are exhaustive in relation to four language functions, such as (A) expressive, (B) signaling, (C) descriptive, and (D) argumentative (POPPER, 1972).

Therefore, Leech, has noticed only that what is missing in Popper's evolutionary epistemology constitutes a link to a world of societal facts, intervening between the second (subjective) and the third (objective) worlds, as and interper- 
sonal and intersubjective world. Like this, Leech's division embraces objects and states of: World 1 - physical, including biological, World 2 - mental, subjective, World 3 - societal, intersubjective, World 4 - scientific and artistic, objective knowledge. (cf. LEECH, 1983, p.51, Table 3.1.)

A similar issue, which appears to be helpful in the understanding of the world beyond signs, is the theory of modeling systems of reality, put forward by Juri Lotman mentioned above, and Thomas A. Sebeok, where the crucial role is ascribed to the semiotic self, as a world-model-builder or world-view-designer. In his theses, published in under the title "The place of art among other modeling systems” [Тезисы к проблеме “Искусство в ряду моделирующих систем]. Lotman describes a model as "an analogue of an object of perception that substitutes for it in the process of perception" (LOTMAN, 2011 [1967], p.250). According to Juri Lotman: "A modeling system is a structure of elements and rules of their combination, existing in a state of fixed analogy to the whole sphere of the object of perception, cognition, or organization. For this reason, a modeling system may be treated as a language." (quoted and cited after LOTMAN, 2011 [1967], p.250).

While taking a constructive stand to Lotman's claim by posing the question (at the Semiotic Society of America Meeting in 1987), "In what sense is language a 'primary modeling system'?", Sebeok submits his modeling systems theory based on the detachment of non-verbal (natural) from verbal (conventional) and non-verbal (cultural) communication systems.

At the same time, Sebeok mentions that it is very likely that the representatives of the species Homo habilis had the capacity of language without any verbal expression, claiming that: "Solely in the genus Homo have verbal signs emerged. To put it in another way, only hominids possess two mutually sustaining repertoires of signs, the zoosemiotic non-verbal, plus, superimposed, the anthroposemiotic verbal." (see SEBEOK, 1988, p.55).

In Sebeok's view, the human being acts as a semiotic self in the capacity of a world-model builder also on the level of biological organisms. Therefore, its primary modeling system of reality is created in the surrounding of animals through the mediation of effectors and receptors, i.e., on the level indexical symptoms and appealing signals (SEBEOK, 1991).

Whereas the secondary modeling system, involving the extralinguistic reality of everyday life, construed by the use of verbal means of signification and communication, appears only in the sphere of humans, the tertiary modeling system, encompassing the extrasemiotic reality of human civilization, being artificially created and generationally transmitted through tradition, entails the 
whole semiosphere of language and culture (discussed and cited after WĄSIK, 2016a, p.132-133).

Worth quoting is the opinion of Susan Petrilli who has supported Sebeok's convictions that: "Thanks to language understood as modeling device and to its syntactical capacity, the human animal, differently from nonhuman animals, is not programmed to remain fixed within a single world, but, on the contrary, is able to build an infinite number of possible worlds through the work of construction, deconstruction, and reconstruction.” (PETRILLI, 2013, p.38-39).

To conclude, one could state that the topic of the creative use of language have been extensively discussed in numerous works about dispositional potentials of human individuals as communication participants as well mental faculties and physiological endowments of human beings as speaking animals. The abilities of humans to create unusual novelties or to perform average innovations in style and form of language as a means of communication, encompass the imaginative altering of abstraction of cognizing and sign-processing subjects, to displace themselves from one existence mode to another and to enter into sometimes inexperienced dimensions of their states of being, or to the assumed states of others while basing on the creative power of knowledge.

The postulative conception of imaginative abilities of humans to create possible or alternative worlds, may finally be supported by the statement of Jørgen Dines Johansen, assuming that "[...] we are programmed by evolution to produce virtual universes in dreaming, in playing, in hypothesizing about the future and in daydreaming.", and what is more, "[...] the production of fictional universes allows us not only to project future changes onto present states of affairs, but also to change the conditions - among other things, the nature and the ontological status of the agents." (quoted and cited from JOHANSEN, 2011, p.219).

\section{REFERENCES}

AVENARIUS, R. Kritik der reinen Erfahrung ('Critique of pure experience'). Leipzig: Fues's Verlag (R. Reisland), 1888. v.1.

AVENARIUS, R. Kritik der reinen Erfahrung ('Critique of pure experience'). Zweiter Band. Leipzig: Fues's Verlag (R. Reisland), 1890. v.2.

BATESON, G. Steps to an ecology of mind: collected essays in anthropology, psychiatry, evolution, and epistemology. Northvale; London: Jason Aronson, 1987. Originally published in 1972, San Francisco, CA for Chandler Publishing Company. 
BATESON, G. Psychiatric thinking: an epistemological approach. In: RUESCH, J.; BATESON, G. Communication: the social matrix of psychiatry. New York: W. W. Norton, 1951. p.228-256.

BATESON, G. Mind and nature: a necessary unity. New York: E. P. Dutton, 1979. BERGER, P. L.; LUCKMANN, T. The social construction of reality. New York: Doubleday, 1966.

BLOCH, E. The principle of hope. Trans. N. Plaice, S. Plaice, P. Knight. Oxford: Basil Blackwell, 1986. v.1-3. Original title: Das Prinzip Hoffnung, Band 1-3, published for Aufbau-Verlag, 1954-1959.

FERRIER, J. F. Institutes of metaphysic: the theory of knowing and being. Edinburgh; London: William Blackwood and Sons, 1854.

HEGEL, G. W. F. Phenomenology of mind. Introduction, notes and translation J. B. Baillie. London: George Allen \& Unwin: Swan Sonnenschein; New York: The Macmillan Company, 1910. Original title: Die Phänomenologie des Geistes: system der Wissenschaft. Erster Theil, published for Verlag Joseph Anton Goebhardt, 1807.

HEIDEGGER, M. On the essence of ground. In: MCNEIL, W. H. (ed.). Martin Heidegger. Pathmarks. Translation W. H. Mcneil. Cambridge: Cambridge University Press, 1998. p.97-135. Original title: Vom Wesen des Grundes. In: Festschrift: Edmund Husserl zum 70. Geburtstag gewidmet, published for Max Niemeyer, 1929. p.71-110.

HEIDEGGER, M. The fundamental concepts of metaphysics: world, finitude, solitude. Translation W. H. Mcneil, N. Walker. Bloomington: Indiana University Press, 1995. Original title: Die Grundbegriffe der Metaphysik: Welt - Endlichkeit Einsamkeit, published for Vittorio Klostermann, 1983.

HEIDEGGER, M. Being and time. Translation J. Macquarrie, E. Robinson. London: SCM Press, 1962. Original title: Sein und Zeit, published for Max Niemeyer, 1929.

HUSSERL, E. The crisis of European sciences and transcendental phenomenology: an introduction to phenomenological philosophy. Translation D. C. Evanston. Illinois: Northwestern University Press, 1970. Original title: Die Krisis der europäischen Wissenschaften und die transzendentale Phänomenologie: eine Einleitung in die phänomenologische Philosophie, published for Martinus Nijhoff, 1954.

JOHANSEN, J. D. Semiotics, biology, and the adaptionist theory of literature. In: COBLEY P.; DEELY, J.; KULL, K.; PETRILLI, S. (ed.). Semiotics continues to 
astonish: Thomas A. Sebeok and the doctrine of signs. Berlin: De Gruyter Mouton, 2011. p.2007-2222.

KANT, I. Critique of pure reason. Trans. F. Haywood. London: William Pickering, 1838. Original title: Critik der reinen Vernunft, published for Johann Friedrich Hartknoch, 1781.

KORZYBSKI, A. Science and sanity: an introduction to non-Aristotelian systems and general semantics. Lancaster: International Non-Aristotelian Library; New York: Science Press Printing, 1933.

LEECH, G. Principles of pragmatics. New York: Longman, 1983.

LOEB, J. Comparative physiology of the brain and comparative psychology. Trans. A. L. Loeb. New York: G. P. Putnam's Sons; London: John Murray, 1900. Original title: Einleitung in die vergleichende Gehirnphysiologie und vergleichende Psychologie: mit besonderer Berücksichtigung der wirbelloser Tiere, published for Johann Ambrosius Barth, 1899].

LOTMAN, J. The place of art among other modeling systems. Trans. T. Pern. Sign Systems Studies, Tartu, v.39, n.2/4, p.249-270, 2011. Original: Лотман, Юрий Михайлович. Тезисы к проблеме "Искусство в ряду моделирующих систем": Труды по знаковым системам, [s. l.], v.3, p.130-145, 1967.

LOTMAN, J. On the semiosphere. Trans. Wilma Clark. Sign Systems Studies, Tartu, v.33, n.1, p.205-229, 2005. Original: Лотман, Юрий Михайлович. О семиосфере. Труды по знаковым системам, [s. l.], v.17 (Тарту), р.5-23, 1984.

LOTMAN, J. The semiotics of culture and the concept of a text. Journal of Russian and East European Psychology, Philadelphia, v.26, n.3, p.52-58, 1988. Original: Лотман, Юрий Михайлович. Семиотика культуры и понятие текста. Труды по знаковым системам, [s.l.], v.12 (Тарту), p.3-7, 1981.

$\mathrm{MACH}, \mathrm{E}$. The analysis of sensations and the relation of the physical to the psychical. Trans. C. M. Williams, from the first German edition; revised and supplemented from the fifth German edition S. Waterlow. Chicago; London: The Open Court Publishing Company, 1914. Original title: Die Analyse der Empfindungen und das Verhältnis des Physischen zum Psychischen, 5.ed., publesed for G. Fischer, 1906.

MACH, E. Contributions to the analysis of the sensations. Trans. C. M. Williams. Chicago: Open Court Publishing Company, 1987. Original title: Beiträge zur Analyse der Empfindungen, 1886. 
MERLEAU-PONTY, M. Phenomenology of perception. Trans. C. Smith. London: Routledge Classics; New York: Taylor and Francis e-Library, 2005. Original title: Phénomènologie de la perception, published for Gallimard, 1945.

MIVART, St. G. J. The groundwork of science: a study of epistemology. New York: G. P. Putnam's Sons; London: Bliss, Sands, 1898.

PETRILLI, S. The self as a sign, the world, and the other: living semiotics. New Brunswick; London: Transaction Publishers, 2013.

POPPER, K. Objective knowledge: an evolutionary approach. Oxford: Oxford University Press, 1972.

SCHÜTZ, A. Der sinnhafte Aufbau der sozialen Welt: Eine Einleitung in die verstehende Soziologie Wien: Julius Springer Verlag, 1932.

SCHÜTZ, A.; LUCKMANN, T. The structures of the life-world. Trans. R. M. Zaner, H. T. Engelhardt Jr. Illinois: Northwestern University Press, 1973. Publication in English: Strukturen der Lebenswelt, published for Luchterhand, 1975.

SEBEOK, T. A. The semiotic self. In: SEBEOK, T. A. A sign is just a sign. Bloomington: Indiana University Press, 1991. p.36-40. First edition: The sign and its masters published for University of Texas Press, 1979, appendix, p.263-267.

SEBEOK, T. A. In what sense is language a 'primary modeling system'? In: SEBEOK, T. A. A sign is just a sign. Bloomington: Indiana University Press, 1988. p.49-58.

SKRIMSHIRE, S. Politics of fear, practices of hope: depoliticisation and resistance in a time of terror. London: Bloomsbury Publishing PLC: United Kingdom, 2009. First edition published for Continuum Books, 2008.

VAN MANEN, M. Phenomenology of practice: meaning-giving methods in phenomenological research and writing (developing qualitative inquiry). California: Left Coast Press, 2014.

VAN MANEN, M. Phenomenology online: a resource from phenomenological inquiry, accessible and offered free at Max van Manen's personal pages, successively since 2011. Available at: http://www.phenomenologyonline.com. Accessed: 10 Apr. 2020 .

VAN MANEN, M. Phenomenology of practice. Phenomenology \& Practice, Edmonton, v.1, n.1, p.11-30, 2007.

VAN MANEN, M. Researching human experience: human science for an action sensitive pedagogy. 2.ed., rev. and corrected. New York: Routledge, 1997. First edition published for State University of New York Press, Althaus Press, 1989. 
WĄSIK, Z. Umwelt, Lebenswelt \& Dasein seen through the lens of a subjective experience of reality. Sign Systems Studies, Tartu, v.46, n.1, p.126-142, 2018.

WĄSIK, Z. From grammar to discourse: towards a solipsistic paradigm of semiotics. Poznań: Adam Mickiewicz University Press in Poznań, 2016a.

WĄSIK, Z. Epistemology - the theory of knowledge or knowing? Appreciating Gregory Bateson's contribution to the cartography of human cognition. Romanian Journal of Communication and Public Relations, [s. l.], v.18, n.3 (39), p.23-35, 2016b.

WĄSIK, Z. Lectures on the epistemology of semiotics. Wrocław: Philological School of Higher Education in Wrocław Publishing, 2014.

WĄSIK, Z. Epistemological perspectives on linguistic semiotics. Frankfurt am Main: Peter Lang, 2003.

WAZSIK, Z. An outline for lectures on the epistemology of semiotics. Opole: Wydawnictwo Uniwersytetu Opolskiego, 1998. 